Eur. J. Clin. Chem. Clin. Biochem.

Vol. 31, 1993, pp. 129-134

(C) 1993 Walter de Gruyter \& Co.

Berlin · New York

\title{
A Comparative Study of Urinary Xanthopterin and Neopterin in Liver Diseases
}

\author{
By Akira Fukuda ${ }^{1}$ ), Toshio Mazda ${ }^{2}$, William L. Gyure ${ }^{3}$, Teruhiko Iino ${ }^{4}$, Hideharu Harada ${ }^{1}$, \\ Michiy'asu Yakura ${ }^{1}$, Hiroshi Kamitsukasa ${ }^{1}$, Akira Ohbayashi ${ }^{1}$, Teruaki Oka ${ }^{5}$ and Motoo Tsusué ${ }^{6}$ \\ 1 Department of Gastroenterology, Liver Unit, Tokyo National Sanatorium Hospital, Kiyose, Tokyo, Japan \\ 2 Japanese Red Cross Tokyo Metropolitan Blood Center, Musashino, Tokyo, Japan \\ 3 Seton Hall University, South Orange, New Jersey, USA \\ ${ }^{4}$ Department of General Education, Nihon University, Setagaya-ku, Tokyo, Japan \\ 5 Department of Pathology, Medical School, Tokyo University, Bunkyo-ku, Tokyo, Japan \\ ${ }^{-}$Biological Laboratory, School of Liberal Arts and Sciences, Kitasato University, Sagamihara, Kanagawa, \\ Japan
}

(Received September 18, 1992)**)

Summary: By adsorption to activated charcoal, various pteridine derivatives in human urine are oxidized to xanthopterin. Following this oxidation, xanthopterin in urine from healthy subjects and from patients with liver diseases was assayed by high performance liquid chromatography. The mean values for xanthopterin in healthy subjects were $532 \pm 116 \mu \mathrm{mol} / \mathrm{mol}$ creatinine (mean $\pm \mathrm{SD}$ ) in males and $585 \pm 153 \mu \mathrm{mol} / \mathrm{mol}$ creatinine in females; the difference was statistically significant $(p<0.01)$. Xanthopterin concentrations in patients with liver disease were significantly higher than those in normal subjects. When compared with urinary neopterin, which is a marker of activated cell immunity, xanthopterin was significantly increased even in fatty liver disease. These findings suggest that increased concentrations of urinary xanthopterin in liver diseases reflect not only the status of activated cell-mediated immunity, but also injury to liver cells.

\section{Introduction}

Many pteridine derivatives have been found in human urine (1). Among these pteridines, neopterin has been used as a biochemical marker of the activated state of cell-mediated immunity, and it has been used to monitor and screen for some clinical disorders $(2-6)$.

Some current studies show that urinary neopterin concentrations in patients with acute or chronic viral hepatitis are higher than in normal controls $(7,8)$. Urinary neopterin has also been utilized to distinguish between chronic non-A,non-B hepatitis and liver steatosis (9).

*) Present address: First Department of Internal Medicine, Osaka Medical College, Takatsuki, Osaka, Japan.

**) Submitted February 10/August 31, 1.992 to "Pteridines", which discontinued with Vol. 3, No. 3, 1992
On the other hand, little information is available on urinary xanthopterin. An early report describes the occurrence of the compound in human urine (1). Urinary xanthopterin and neopterin concentrations are found to be higher in some cancer patients $(10$, 11). Plesner \& Kalckar (12) showed that many pteri-dine derivatives in urine can be oxidized, adsorbed and eluted from activated charcoal to yield stable xanthopterin. Because pteridine metabolism takes place mainly in liver (13), the excretion of other pteridine derivatives, besides neopterin, may possibly be an indicator of liver disease. In our preliminary study, applying Plesner \& Kalckar's extraction method, we assayed urinary xanthopterin in patients with chronic non- $A$, non-B hepatitis and in patients with fatty liver disease (14). In the present paper we assayed urinary xanthopterin in different types of liver disease. Urinary neopterin was also determined for comparison. 


\section{Patients and Methods}

Healthy individuals

As controls, urine samples were collected from 178 apparently healthy individuals (age 21 to 64 years, mean age 42 ), 64 were males (age 24 to 63, mean age 44 ) and 114 females (age 21 to 64 , mean age 40 ). The samples were collected during routine medical examinations for health care workers at the Tokyo National Sanatorium Hospital.

\section{Patients with liver disease}

Urine samples were collected from in- and out-patients in the liver unit, Tokyo National Sanatorium Hospital. The patients were divided into 5 groups as follows;

1) acute viral hepatitis 8 cases,

2) chronic viral hepatitis 53 cases,

3) liver cirrhosis 21 cases,

4) alcohol-induced liver disease 18 cases and

5) non-alcoholic fatty liver 13 cases.

The results of routine biochemical liver tests in each group are shown in table 1.

Among the acute viral hepatitis cases ( 4 males and 4 females, mean age 37 years), 5 were type A (anti-IgM HAV antibody positive), 1 was type $B$ (HBs antigen and anti-IgM $\mathrm{HBc}$ antibody positive) and 2 were type $C$ (both above $\mathrm{HAV}$ and $\mathrm{HBV}$ markers negative and anti-c100-3 positive). Of the chronic viral hepatitis cases ( 27 males and 26 females, mean age 57 years), 10 were type $B, 33$ were type $C$ and the other 10 were type non-A,non-B,non-C. Among the chronic viral hepatitis cases, histological features on liver biopsy showed chronic persistent hepatitis in 20 and chronic active hepatitis in 33. Of the liver cirrhosis cases (16 males and 5 females, mean age 60 years), 12 were type B, 2 were type $C$ and 7 were type non-A,non-B,nonC. All the cases were non-alcoholic with biopsy results showing postnecrotic cirrhosis. The alcohol-induced liver disease cases (all 18 were males, mean age 52 years) had a long history of alcohol abuse, with histological features showing either fatty liver or alcoholic fibrosis with or without fat deposits. The nonalcoholic fatty liver cases (12 males and 1 female, mean age 43 years) were considered to be due to obesity and/or metabolic abnormalities such as hyperlipaemia or non-insulin-dependent diabetes.

Renal failure was not present in any of the study subjects, according to urinary and serologic tests. In addition no drugs such as azathiopurine, corticosteroids or interferon were given in the 6 months prior to this study.

\section{Urine and blood sample analysis}

After the measurement of creatinine concentrations by the alkaline picrate method, urine samples were immediately stored at $-30^{\circ} \mathrm{C}$ in the dark until used for the measurement of xanthopterin and neopterin.

Blood samples were taken from all test subjects at the Tokyo National Sanatorium Hospital at the time of urine collection. Serum tests were performed for the following enzymes; alanine aminotransferase, aspartate aminotransferase, $\gamma$-glutamyl transferase. As a screening test, the zinc turbidity test was also performed.

All analyses were conducted using a 736-40E multi-channel autochemical analyser (Hitachi Co., Ltd., Tokyo, Japan).

\section{Urinary xanthopterin assay}

Urinary xanthopterin was measured applying the isolation method of Plesner \& Kalckar (12) and using high performance liquid chromatography (HPLC) for quantitation as follows: To $6 \mathrm{mg}$ of activated charcoal (Norit A or Norit SX-3) $10 \mu \mathrm{l}$ of $1 \mathrm{~mol} / \mathrm{l}$ acetic acid and $1 \mathrm{ml}$ of urine were added successively, mixed, and allowed to stand at room temperature for $10 \mathrm{~min}$ utes. The mixture was centrifuged at $6700 \mathrm{~g}$ for 5 minutes. The resulting precipitate was washed once with distilled water, then resuspended in $500 \mu \mathrm{l}$ of $0.05 \mathrm{~mol} / 1 \mathrm{NaOH}$ containing $20 \mathrm{ml} / \mathrm{l}$ pyridine. This mixture was centrifuged at $6700 \mathrm{~g}$ for 5 minutes and after a 10 fold dilution of the supernate with distilled water, $50 \mu \mathrm{l}$ of the solution was injected into the HPLC system.

For xanthopterin determinations, the Twincle HPLC system (Japan Spectroscopic Co., Ltd., Tokyo, Japan) was used. For fluorescence detection, a Jasco FP-110 spectrophotometer (Japan Spectroscopic Co., Ltd., Tokyo, Japan) was used with excitation at $390 \mathrm{~nm}$ and emission measurement at $460 \mathrm{~nm}$. A cut-off filter was used to eliminate detection of emission wave lengths shorter than $460 \mathrm{~nm}$. Peaks were recorded on a D-2000 chromato integrator (Hitachi Co., Ltd., Tokyo, Japan). The HPLC column was packed with Asahipac GS 320H (Asahi Chemical Industry Co., Ltd., Kawasaki, Japan). The elution fluid was methanol (volume fraction 0.10 ) containing $10 \mathrm{mmol} / 1$ potassium phosphate buffer pH 7.0 at a flow rate of $1 \mathrm{ml}$ per minute. The main peak, which showed a retention time of 10.5 minutes, was identified as xanthopterin by comparison with authentic xanthopterin using the HPLC system described above.

The values were expressed as $\mu \mathrm{mol}$ xanthopterin per mol creatinine.

Tab. 1. Biochemical liver tests in each group of liver diseases

\begin{tabular}{|c|c|c|c|c|c|}
\hline \multirow{2}{*}{$\begin{array}{l}\text { Cases } \\
\text { Reference range }\end{array}$} & \multirow[t]{2}{*}{ (n) } & $\begin{array}{l}\text { Alanine } \\
\text { aminotransferase }\end{array}$ & \multirow{2}{*}{$\begin{array}{l}\text { Aspartate } \\
\text { aminotransferase } \\
\text { (31-9 IU/l) } \\
\text { mean (range) }\end{array}$} & \multirow{2}{*}{$\begin{array}{l}\gamma \text {-Glutamyl- } \\
\text { transferase } \\
(33-4 \mathrm{mU} / \mathrm{l}) \\
\text { mean (range) }\end{array}$} & \multirow{2}{*}{$\begin{array}{l}\text { Zinc } \\
\text { turbidity test } \\
\text { (13-1 Kunkel U) } \\
\text { mean (range) }\end{array}$} \\
\hline & & $\begin{array}{l}(34-4 \mathrm{IU} / \mathrm{l}) \\
\text { mean (range) }\end{array}$ & & & \\
\hline Acute hepatitis & (8) & $1338(254-3468)$ & $776(59-2428)$ & $130(54-193)$ & $11(6-22)$ \\
\hline active & (33) & $143(49-288)$ & $117(37-279)$ & $92(19-425)$ & $17(5-28)$ \\
\hline persistent & (20) & $48(19-95)$ & $41(22-61)$ & $39(12-126)$ & $15(4-24)$ \\
\hline Liver cirrhosis & (21) & $66(10-183)$ & $82(14-224)$ & $67(17-253)$ & $17(7-31)$ \\
\hline $\begin{array}{l}\text { Alcohol-induced } \\
\text { liver disease }\end{array}$ & (18) & $59(13-185)$ & $81(24-212)$ & $198(24-726)$ & $10(2-31)$ \\
\hline $\begin{array}{l}\text { Non-alcoholic } \\
\text { fatty liver }\end{array}$ & (13) & $47(20-75)$ & $39(19-97)$ & $74(13-264)$ & $7(3-13)$ \\
\hline
\end{tabular}




\section{Urinary neopterin assay}

Urinary neopterin was directly assayed without oxidation (15) using a RIA kit "IMMUtest Neopterin" (Henning Berlin $\mathrm{GmbH}$, Berlin, Germany). Radioactivity was counted by a programmed gamma-counter "ANSR" (Dinabot Co., Ltd., Tokyo, Japan).

The values were expressed as $\mu \mathrm{mol}$ neopterin per mol creatinine.

\section{Statistical analysis}

The differences of xanthopterin values in healthy subject between different age groups were assessed by the Kruskal-Wallis test. Using urinary xanthopterin and neopterin assay values as data, median values for these pteridines were determined under various conditions and evaluated by the Mann-Whitney U-test. Comparisons of abnormal levels of xanthopterin and neopterin were assessed by the $\chi^{2}$-test for the different groups of patients separately.

\section{Results}

\section{Urinary $x$ anthopterin in healthy individuals}

In 178 healthy subjects, the mean values of xanthopterin were $566 \pm 143 \mu \mathrm{mol} / \mathrm{mol}$ creatinine (mean $\pm \mathrm{SD})$. In 64 males the values were $532 \pm 116 \mu \mathrm{mol} /$ mol creatinine and in 114 females $585 \pm 153 \mu \mathrm{mol} /$ mol creatinine. Although a statistical difference in urinary xanthopterin concentrations for males and females was found in this present study $(p<0.01)$, there were no statistically significant age group differences ( $p>0.05$ ), as shown in table 2 .

\section{Urinary $x$ anthopterin}

\section{in liver disease patients}

As shown in table 3, urinary xanthopterin concentrations in patients with liver disease including nonalcoholic fatty liver were significantly higher than those in healthy subjects. The highest concentrations of xanthopterin were found in the acute hepatitis
Tab. 2. Urinary excretion of xanthopterin and neopterin in healthy individuals

\begin{tabular}{llll}
\hline $\begin{array}{l}\text { Age } \\
\text { (years) }\end{array}$ & $\begin{array}{l}\text { Number } \\
\text { of cases }\end{array}$ & $\begin{array}{l}\text { Xanthopterin } \\
(\mu \mathrm{mol} / \mathrm{mol} \\
\text { creatinine })\end{array}$ & $\begin{array}{l}\text { Neopterin } \\
(\mu \mathrm{mol} / / \mathrm{mol} \\
\text { creatinine })\end{array}$ \\
& & mean $\pm \mathrm{SD}$ & mean $\pm \mathrm{SD}$ \\
\hline
\end{tabular}

\section{Males}

$\begin{array}{lrll}24-29 & 8 & 527 \pm 131 & 98 \pm 55 \\ 30-39 & 18 & 517 \pm 90 & 82 \pm 27 \\ 40-49 & 15 & 556 \pm 82 & 90 \pm 42 \\ 50-63 & 23 & 529 \pm 148 & 95 \pm 39 \\ \text { Total } & 64 & 532 \pm 116 & 91 \pm 39 \\ & & & \\ \text { Females } & & 555 \pm 92 & 105 \pm 26 \\ 21-29 & 24 & 592 \pm 143 & 117 \pm 26 \\ 30-39 & 31 & 575 \pm 176 & 125 \pm 39 \\ 40-49 & 27 & 608 \pm 178 & 130 \pm 44 \\ 50-64 & 32 & 585 \pm 153 & 120 \pm 38 \\ \text { Total } & 114 & & \end{array}$

patients, and xanthopterin concentrations were also high in chronic active hepatitis. Urinary xanthopterin concentrations in the active stages of chronic hepatitis were statistically higher than in the persistent stages (chronic active hepatitis vs. chronic persistent hepatitis: $\mathrm{p}<0.01$ ).

\section{Comparison with urinary neopterin}

Urinary neopterin concentrations for the same subjects are also shown in table 3 . Neopterin was significantly elevated in cases of acute hepatitis, chronic hepatitis, liver cirrhosis and alcohol-induced liver disease, when compared with normal subjects. In nonalcoholic fatty liver cases, however, there was no significant elevation of neopterin.

Urinary concentrations of xanthopterin and neopterin in all groups of liver disease are shown in figure 1.

Tab. 3. Urinary excretion of xanthopterin and neopterin

\begin{tabular}{|c|c|c|c|c|c|c|c|}
\hline \multirow[t]{2}{*}{ Group } & \multirow[t]{2}{*}{ (n) } & \multicolumn{2}{|c|}{$\begin{array}{l}\text { Xanthopterin } \\
\text { ( } \mu \mathrm{mol} / \mathrm{mol} \text { creatinine) }\end{array}$} & \multirow[t]{2}{*}{$\mathrm{p}$} & \multicolumn{2}{|c|}{$\begin{array}{l}\text { Neopterin } \\
(\mu \mathrm{mol} / \mathrm{mol} \text { creatinine })\end{array}$} & \multirow[t]{2}{*}{$\mathrm{p}$} \\
\hline & & Mean $\pm S D$ & Range & & Mean $\pm S D$ & Range & \\
\hline $\begin{array}{l}\text { Control } \\
\text { Acute hepatitis } \\
\text { Chronic hepatitis }\end{array}$ & $\begin{array}{r}178 \\
8\end{array}$ & $\begin{array}{r}566 \pm 143 \\
1305 \pm 579\end{array}$ & $\begin{array}{l}250-902 \\
813-2201\end{array}$ & $<0.001$ & $\begin{array}{l}109 \pm 40 \\
769 \pm 571\end{array}$ & $\begin{array}{r}27-232 \\
266-1791\end{array}$ & $<0.001$ \\
\hline $\begin{array}{l}\text { active } \\
\text { persistent } \\
\text { Liver cirrhosis } \\
\text { Alcohol-induced } \\
\text { liver disease }\end{array}$ & $\begin{array}{l}33 \\
20 \\
21 \\
18\end{array}$ & $\begin{array}{l}978 \pm 174 \\
807 \pm 261 \\
934 \pm 251 \\
868 \pm 248\end{array}$ & $\begin{array}{l}564-1377 \\
536-1462 \\
505-1325 \\
418-1347\end{array}$ & $\begin{array}{l}<0.001 \\
<0.001 \\
<0.001 \\
<0.001\end{array}$ & $\begin{array}{l}251 \pm 92 \\
224 \pm 94 \\
227 \pm 99 \\
154 \pm 48\end{array}$ & $\begin{array}{l}91-463 \\
91-422 \\
90-452 \\
71-240\end{array}$ & $\begin{array}{l}<0.001 \\
<0.001 \\
<0.001 \\
<0.001\end{array}$ \\
\hline $\begin{array}{l}\text { Non-alcoholic } \\
\text { fatty liver }\end{array}$ & 13 & $689 \pm 183$ & $435-993$ & $<0.05$ & $125 \pm 42$ & $74-207$ & NS \\
\hline
\end{tabular}

NS: not significant compared with controls 

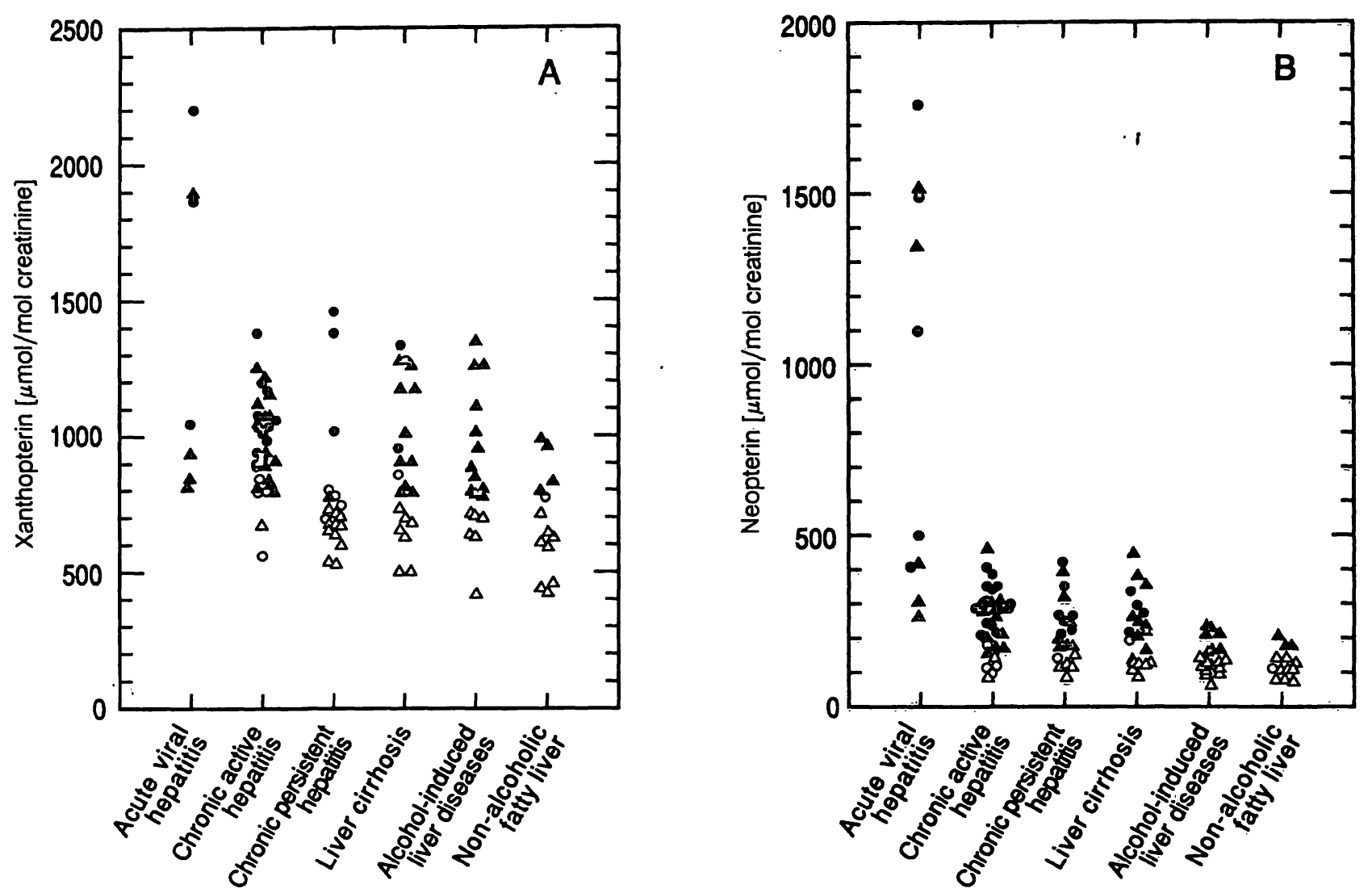

Fig. 1. Urinary concentrations of xanthopterin (A) and neopterin (B) in all groups of liver disease.

$\Delta:$ males within, $\Delta$ : males outside the range $\bar{x}+2 \mathrm{SD}$ of healthy male controls.

$\mathrm{O}$ : females within, $\mathrm{o}$ : females outside the range $\overline{\mathrm{x}}+2 \mathrm{SD}$ of healthy female controls.

Tab. 4. Abnormal rates of xanthopterin and neopterin excretion in all groups of liver disease. The relative and absolute frequency of patients having a measured value greater than the mean $+2 \mathrm{SD}$ of normal controls are shown

\begin{tabular}{|c|c|c|c|c|}
\hline \multirow[t]{2}{*}{ Disease } & \multicolumn{2}{|c|}{ Xanthopterin } & \multicolumn{2}{|c|}{ Neopterin } \\
\hline & $\%$ & $\mathrm{n}$ & $\%$ & $\mathbf{n}$ \\
\hline $\begin{array}{l}\text { Acute hepatitis } \\
\text { Chronic hepatitis }\end{array}$ & 88 & $(7 / 8)$ & 100 & $(8 / 8)$ \\
\hline active & 82 & $(27 / 33)$ & 79 & $(26 / 33)$ \\
\hline persistent & 25 & $(5 / 20)$ & 70 & $(14 / 20)$ \\
\hline Liver cirrhosis & 67 & $(14 / 21)$ & 62 & $(13 / 21)$ \\
\hline $\begin{array}{l}\text { Alcohol-induced } \\
\text { liver disease }\end{array}$ & 67 & $(12 / 18)$ & 39 & $(7 / 18)$ \\
\hline $\begin{array}{l}\text { Non-alcoholic } \\
\text { fatty liver }\end{array}$ & 31 & $(4 / 13)$ & 23 & $(3 / 13)$ \\
\hline
\end{tabular}

When the normal upper limit of each pteridine was set at the mean $+2 \mathrm{SD}$ in healthy controls, then abnormal rates were highest in acute hepatitis and chronic active hepatitis as seen in table 4. Mean +2 SD for xanthopterin was $764 \mu \mathrm{mol} / \mathrm{mol}$ creatinine in males and $891 \mu \mathrm{mol} / \mathrm{mol}$ creatinine in females, and for neopterin it was $169 \mu \mathrm{mol} / \mathrm{mol}$ creatinine in males and $196 \mu \mathrm{mol} / \mathrm{mol}$ creatinine in females. There was a significant difference in xanthopterin concen- trations between chronic active hepatitis and chronic persistent hepatitis $(82 \%$ and $25 \%, \mathrm{p}<0.001)$, while neopterin did not show this difference $(79 \%$ and $70 \%$, $\mathrm{p}>0.05$ ).

\section{Discussion}

In the present paper a new method of urinary xanthopterin assay after treatment with activated charcoal is presented. Using this method we assayed urinary xanthopterin in healthy individuals and in patients with liver disease. In healthy subjects xanthopterin and neopterin concentrations when expressed in $\mu \mathrm{mol} / \mathrm{mol}$ creatinine were higher in females than in males, but there were no significant age-differences in this study. In our study populations, the concentrations of urinary xanthopterin in all groups with liver disease were significantly higher when compared with healthy subjects. Neopterin concentrations were also raised, but in agreement with Prior et al. (9), there was no significant elevation of neopterin in non-alcoholic fatty liver.

Urinary or serum neopterin cỏhcentrations are raised in infectious or malignant disorders with activated cell-mediated immunity $(4-6)$. Neopterin is mainly 
produced in human monocytes/macrophages, and its release is accelerated upon stimulation by interferon- $\gamma$ (3). In our study, urinary neopterin concentrations were very high in acute hepatitis, and high in virusinduced chronic liver diseases. In alcoholic liver diseases, neopterin concentrations were only slightly higher than in controls. This finding may support the view that alcoholic hepatitis successively activates cellmediated immunity, and that the progress of liver damage in spite of alcohol abstinence, is responsible for the hyperimmune reactivity $(16,17)$.

The biochemistry of xanthopterin production and excretion is still scarcely known. Nevertheless, we assayed xanthopterin together with neopterin. Surprisingly, xanthopterin concentrations were significantly high in all the liver disease groups mentioned above. The increase in urinary xanthopterin, like that of neopterin, in liver diseases may also be caused by activated cell immunity, because the concentrations of both are roughly correlated.

However, abnormally elevated concentrations of xanthopterin were found in $82 \%$ of patients with chronic active hepatitis, but in only $25 \%$ of patients with chronic persistent hepatitis $(p<0.001)$. These two groups were histologically differentiated from those with severe parenchymal destruction. With respect to neopterin excretion, however, these two groups were not significantly different $(79 \%$ and $70 \%, p>0.05)$. Moreover, the rate of occurrence of abnormally elevated urinary xanthopterin in fatty liver and other chronic liver diseases appear to parallel the mean values of serum aminotransferase activities. This cor- relation does not exist for neopterin excretion. These findings indicate that increased urinary xanthopterin reflects liver-cell damage rather than the hyperimmune state.

When solutions $\left(10^{-5} \mathrm{~mol} / \mathrm{l}\right)$ of dihydroxanthopterin, xanthopterin, dihydroneopterin or tetrahydrobiopterin were mixed with equal volumes of urine and assayed by the present method, the xanthopterin concentrations were found to be 1.8, 1.5, 1.3 and 1.4 times the basal concentration (unpublished data). However, when neopterin, biopterin or dihydrobiopterin were examined by this method, no increase in urinary xanthopterin was observed. Thus, the present method represents an assay for dihydroxanthopterin, dihydroneopterin and tetrahydrobiopterin in urine.

After treatment with activated charcoal, eluates obtained by this method were fairly pure, and an HPLC column could be used for hundreds of samples without column washing. A further convenient feature of this HPLC method is that it can be utilized in laboratories where only a fluorometer is available (12).

Further studies will be undertaken of the biochemical processes leading to the raised excretion of xanthopterin.

\section{Acknowledgements}

We wish to thank Dr. K. Shibata, Hoechst Japan Co., Ltd., for the generous supply of RIA kits; Mr. K. Fukuhara, Mr. $M$. Nagashima and his coworkers at Tokyo National Sanatorium Hospital for generous assistance; and Dr. T. Katayama, Director of the Tokyo National Sanatorium Hospital, for his help in this study.

\section{References}

1. Fukushima, T. \& Shiota, T. (1972) Pterins in human urine. J. Biol. Chem. 247, 4549-4556.

2. Wachter, H., Hausen, A. \& Grassmayr, K. (1979) Erhöhte Ausscheidung von Neopterin im Harn von Patienten mit malignen Tumoren und mit Viruserkrankungen. HoppeSeyler's Z. Physiol. Chem. 360, 1957-1960.

3. Huber, C., Batchelor, J. R., Fuchs, D., Hausen, A., Lang, A., Niederwieser, D., Reibnegger, G., Swetly, P., Troppmair, J. \& Wachter, H. (1984) Immune response-associated production of neopterin. Release from macrophages primarily under control of interferon-gamma. J. Exp. Med. 160, $310-316$.

4. Hausen, A., Bichler, A., Fuchs, D., Hetzel, H., Reibnegger, G. \& Wachter, H. (1985) Neopterin, a biochemical indicator of cellular immune reactions, in the detection and control of patients with neoplastic díseases. Cancer Detection and Prevention 8, 121-128.

5. Fuchs, D., Hausen, A., Reibnegger, G., Werner, E. R., Dierich, M. P. \& Wachter, H. (1988) Neopterin as a marker for activated cell-mediated immunity: Application in HIV infection. Immunol. Today 9, 150-155.

6. Hausen, A.. Fuchs, D., Reibnegger, G., Worner, E. R. \& Wachter, H. (1989) Neopterin in clinical use. Pteridines $I$, 3-10.

7. Farci, A. M. G., Laconi, R., Cabras, F., Loviselli, A., Cappai, G., Balestrieri, A., Garau, V. L., Tocco, M. \& Casula, D. (1985) Urinary neopterin in acute and chronic liver diseases. In: Biochemical and Clinical Aspects of Pteridines (Wachter, H., Curtius, H. C. \& Pfleiderer, W., eds.) Berlin-New York, Walter de Gruyter, pp. 453-460.

8. Reibnegger, G., Auhuber, I., Fuchs, D., Hausen, A., Judmaier, G., Prior, C., Werner, E. R. \& Wachter, H. (1988)Urinary neopterin levels in acute viral hepatitis. Hepatology 8, $771-774$.

9. Prior, C., Fuchs, D., Hausen, A., Judmaier, G., Reibnegger, G., Werner, E. R., Vogel, W. \& Wachter, H. (1987) Potential of urinary neoptcrin excretion in differentiating chronic non-A,non-B hepatitis from fatty liver. Lancet $i i, 1235-$ 1237.

10. Rokos, H., Rokos, K., Frisius, H. \& Kirstaedter, H.-J. (1980) Altered urinary excretion of ptertidines in neoplastic disease. Determination of biopterin, neopterin, xanthopterin, and pterin. Clin. Chim. Acta 105, 275-286.

11. Stea, B., Halpern, R. M., Halpern, B. C. \& Smith, R. A. (1981) Urinary excretion levels of unconjugated pterins in cancer patients and normal individuals. Clin. Chim. Acta $113,231-242$. 
12. Plesner, P. \& Kalckar, H. M. (1956) Enzymic micro determinations of uric acid, hypoxanthine, xanthine, adenine, and xanthopterine by ultraviolet spectrophotometry. Methods of Biochemical Analysis 3, 97-110.

13. Fukushima, K., Eto, I., Mayumi, T., Richter, W., Goodson, S. \& Shiota, T. (1975) Biosynthesis of pterins in mammalian systems. In: Chemistry and Biology of Pteridines (Pfleiderer, W., ed.) Berlin-New York, Walter de Gruyter, pp. 247263.

14. Mazda, T., Ogasawara, K., Fukuda, A., Gyure, W. L. \& Tsusué, M. (1990) Urinary xanthopterin and derivatives as indicators of liver disease. In: Chemistry and Biology of Pteridines 1989 (Curtius, H. C., Ghisla, S. \& Blau, N., eds.) Berlin-New York, Walter de Gruyter, pp. 579-582.
15. Fuchs, D.., Milstien, S., Krämer, A., Reibnegger, G., Werner, E. R., Goedert, J. J., Kaufman, S. \& Wachter, H. (1989) Urinary neopterin concentrations vs total neopterins for clinical utility. Clin. Chem. 35, 2305-2307.

16. Kanagasundaram, N., Kakumu, S., Chen, T. \& Leevy, C. M. (1977) Alcoholic hyalin antigen (AHAg) and antibody (AHAb) in alcoholic hepatitis. Gastroenterology 73, 13681373.

17. Izumi, N., Hasumura, Y. \& Takeuchi, J. (1983) Lymphocyte cytotoxicity for autologous human hepatocytes in alcoholic liver disease. Clin. Exp. Immunol. 53, 219-224.

Toshio Mazda, PhD.

Japanese Red Cross

Tokyo Metropolitan Blood Center

1-26-1, Kyonan-cho

Musashino

Tokyo 180

Japan 